\title{
Inspiration from an Admiring Role Model - Woo Sun Food Factory Company
}

\author{
Wu Kei-Chou \\ Feng Chia University \\ E-mail addressww295353@yahoo.com
}

\begin{abstract}
This study investigates the evolution of an admiring food processing plant. Agriculture is once the foundation of Taiwan. Agriculture has a great influence on the food processing industry as well. As a result, as agriculture grows, the food processing industry also develops rapidly. Later on, processed food export becomes important to Taiwan's economy. Meanwhile, the food processing industry is also influenced by the political and economic environment profoundly. Woo Sun Food Factory Company (Woo Sun) is one of the greatest food processing company in Taiwan. Through the four transformations, Woo Sun upgrades technologies and lowers production costs together with the sales cost. Through studying the case study of Woo Sun, a representative food processing company in the Taiwan food industry, we know that management, developing strategies, and manufacturing technology upgrade are extremely important.
\end{abstract}

Keywords: food processing, transformation

\section{INTRODUCTION}

This is an open access article under the CC-BY-NC license.

In the fast-changing global market, every industry faces huge challenges, such as the evolution of the market and the changes in the economic environment. Enterprises must adjust to the fastchanging environment. The food industry is crucial for every country. It closely relates to a country's development and living quality. Food safety will be important for every country in the future as well. Even though the high technology industry becomes more important now, the agriculture and food industry are always the foundation of a country. For long term development and a stable living environment, we need to work hard for the consistent development of the food industry.

Depending on the sales type, there are three important periods of the Taiwan food industry (Food Industry Research and Development Institute, 2015): 1950s export orientation period, 1970s domestic need orientation period, and 2000s specific consumption and high added values product orientation period.

With the support of government policy, food industry plants are able to upgrade technologies and expand the business into the global market. There is a time when the consumer behaviors change, such as canned food consumption becomes less, and the frozen food takes a turn being the bestselling export products (Chi and Xiao, 2006). In general, the food industry earns a huge amount of foreign 
currency for Taiwan and helps to develop the country. Later on, the government also encourages the food processing plant to move overseas to Southeast Asia and China.

Furthermore, starting from the 1970s, research regarding the Taiwan food industry develops rapidly, such as food science, agricultural economics, and agricultural chemistry. With the help of those studies, the food industry is able to apply technologies and management theories to transform to consumer orientation when production costs go skyrocketing high, and the food industry loses its export advantages in the 2000s, as shown in Table 1. Also, developing customized products and functional foods may be solutions to the industrial challenge as well.

Table 1. Adapted from the Food Industry Development (Food Industry Research and Development Institute, 2015)

\begin{tabular}{|c|c|c|c|c|}
\hline Year & 1952 & 1972 & 2002 & 2014 \\
\hline $\begin{array}{c}\text { Processed food in } \\
\text { the total export } \\
\text { ratio (\%) }\end{array}$ & 69.8 & 9.9 & 1.3 & 0.9 \\
\hline $\begin{array}{c}\text { Market } \\
\text { Orientation }\end{array}$ & Export $>$ Domestic demand > Specific consumption and high added values \\
\hline Roles & $\begin{array}{c}\text { Foreign } \\
\text { exchange } \\
\text { earnings }\end{array}$ & $\begin{array}{c}\text { Raising product } \\
\text { value and farmers' } \\
\text { income }\end{array}$ & $\begin{array}{c}\text { Satisfying food } \\
\text { needs and improving } \\
\text { life quality }\end{array}$ & $\begin{array}{c}\text { Providing healthy } \\
\text { and convenient food } \\
\text { to satisfy food and } \\
\text { dietary supplement } \\
\text { needs }\end{array}$ \\
\hline
\end{tabular}

This study learns from the development of the Taiwan food industry, the reasons why the industry becomes prosperous and why it turns otherwise, the changes in the global market, and the case study of one of the greatest food processing companies - the Woo Sun Food Factory. Through analysis of the Taiwan food industry and seeking strategies for the future, visions of future Taiwan food industry development and management will be clear.

\section{LITERATURE REVIEW}

The food industry is always the foundation of a country. Furthermore, according to the 《Global Food Industry Survey 2013-2014》, the global food industry is with high expanding potential (Canadean, 2013).

European Food Industry (Food Industry Research and Development Institute, 2018):

The European markets are more of a high-end market. As a result, the European food industry focuses more on food safety and sustainable environmental issues, which makes the European food processing plants to such food safety and environmental issues.

US Food Industry (Food Industry Research and Development Institute, 2018):

In the US, there are considerably more consumers who have a special love for vegetarian material, artificial protein, and healthy food, which leads the US food industry in the direction of 
healthy and anti-aging products. It is also anticipated that e-commerce will take the US food industry to a whole new stage.

Taiwan Food Industry (Food Industry Research and Development Institute, 2018):

The food export amount counts for $4.6 \%$ of the entire export amount of Taiwan, with the import amount about 2.6 times the export amount. Recently, food safety events take the food industry development directions to food safety reinforcement, global market arrangement, virtual and physical sales channels integration.

The Taiwan food industry is once the most important industry in Taiwan, which contributes to most of the foreign earnings back in the 1950s. The fast-growing food industry is a result of economic policy, including land reform, agricultural policy, and trade policy. Crucial areas of the food industry include raw-material production, food processing technique upgrade, food processing certifications, and export subsidy (Lee, 1997). Food processing not only becomes one of the most important income of Taiwan but also help many poor farmers build up wealth. The prosperous Taiwan food industry is evidence of the achievement of Taiwan's economic policy (Wang, 2017).

In the 1970s, studies regarding the Taiwan food industry emerge. For example, there are many investigations of Food Science, Agricultural Economics, and Agricultural Chemistry. Even the food export becomes less important after the 1980s with the change of economic policy, the development of food processing techniques provides an opportunity for food processing facilities and companies to transform into producing high-added value, functional and customer-oriented products (Chang, 2006).

Also, some severe food safety events also happen around that time, which endanger the lives of many people and cause irreversible damages. The food safety system is built then (Jeng and Fang, 2003).

Organization Transformation Definitions:

a. System-based: The system-based and irreversible changing process is called transformation (Adams, 1984).

b. Structure-based: The changing process involves organizational changes and can be quantitative and multidimensional (Lavy and Marry, 1988).

c. Strategy-based: Any strategies taken as a response when a company faces operational difficulties are transformations (Davidson, 1993).

d. Thought-based: Changes in thoughts are transformation (Wycoff and Richardson, 1995).

From these common transformation definitions, it is clear that transformation includes the actual changes in organizational structure, strategies in response to the environment, and changes in thoughts. Even there are different types of transformations, the main point of transformation is always "changes" in response to challenges or the environment.

\section{RESEARCH METHODOLOGY}

This study started from an observation of the global food industry together with a further observation in the Taiwan food industry. The observation of the Taiwan food industry was further discussed with the change of policy and the economic environment as a result of the literature study. After the brief introduction of the Taiwan food industry, the Porter five forces analysis (Porter, 1979) and the case study of Woo Sun gave an inspiring example of how a small domestic factory expanding its sales into the global markets.

From the perspective of Porter's five forces analysis, buyers have good bargaining power in the food industry. Nowadays, with the change in business models, consumers can access suppliers more easily and have better bargaining abilities. In contrast, suppliers' bargaining power is weakened 
in the emerging business models, such as e-commerce, virtual channels, and key opinion leaders. As the entry threshold for the food industry is not high, so the threat of potential entrants is also relatively large. On the other hand, due to advances in food technology, threats from substitutes and existing competitors are increasing as well. Remaining in the same situation and not moving forward will make a company easy to lose competitiveness in the industry. In order to maintain its own advantages and be more competitive, an enterprise must review the past, look up to the future, and seek solutions from successful role models.

In the case study of Woo Sun Food Factory, the four transformation details were well examined and analyzed based on organization transformation definitions.

\section{FINDING AND DISCUSSION}

\section{Case Study-Woo Sun Food Factory Company}

In a turbulent market, it is possible to create different results through learning and changing. The Woo Sun Food Factory is a role model of Taiwan's food industry history. With the help of government policy and its efforts, the Woo Sun Food Factory quickly rose in the Taiwan food industry. Although the Woo Sun Food Factory had outstanding achievements in various periods, it re-examined its status and connection to the market and adjusted its developing direction. The Woo Sun Food factory had four major transformations.

In the first transformation, the Woo Sun Food Factory focused on technology and quality upgradation, providing quality products, and expanding its business into new markets. There were many difficulties in the preservation of processed foods, so it could not provide products with long shelf life. However, it was also at that time; the Woo Sun Food Factory started using tinplate as the can material instead of glass containers, which prolonged the shelf life and increased product added values. At the same time, the Woo Sun Food Factory also started new product lines. Through cooperation with the Food Industry Research and Development Institute, manufacturing technologies were greatly improved. It enabled the Woo Sun Food Factory to better monitor the quality of the finished product and provide consumers with excellent products.

This transformation can be classified as a system-based (Adams, 1984), strategy-based (Davidson, 1993), and thought-based transformation (Wycoff and Richardson, 1995) from the organization transformation definitions discussed above.

The second transformation focused on expanding its business into the global market. Under the government export policy, export subsidies covered many agricultural (Lee, 1997). However, "straw mushrooms," one of the most seen mushrooms in Taiwan, were not included in the export subsidy. Through innovative thinking and positive actions, the Woo Sun Food Factory Company brought straw mushrooms to the global market. The Woo Sun Food Factory Company also cooperate with Farmers' associations, which also made the farmers able to grow straw mushrooms in their free time. At the same time, the farm equipment could thus be productive all year round. Also, in order to export products, Woo Sun must meet all food hygiene regulations (Jeng and Fang, 2003), which also helped Woo Sun provide quality products.

This transformation is greatly influenced by the Taiwan economic policy. Also, the transformation is a strategy-based transformation (Davidson, 1993), which aligns the development strategy of Woo Sun Food Factory company with Taiwan's economic policy.

The third transformation focused on overseas marketing and promotion and alliance marketing. At that time, Taiwan's economy was pretty good. The cost of labor became record high. As a result, production costs kept growing, especially the cost of labor. The soaring production cost made products hard to compete with neighboring countries with low-cost manpower. Therefore, Woo Sun moved the plant to the developing Southeast Asia region to reduce the production cost and then transported the materials back to Taiwan for further processing and exportation. In addition, Woo 
Sun started to cooperate with partners for Chinese-style canned foods, expanding its business into greater sales markets. Such cooperation also remediated the operational challenges that Woo Sun faced.

This transformation is a system-based (Adams, 1984) and strategy-based transformation (Davidson, 1993), which lowers the production cost and increase the profit significantly.

The fourth transformation was to build a food processing plant in Vietnam. To the Woo Sun Food Factory, reducing the cost of raw material alone was no longer enough to maintain the competitiveness for product export. Manufacturing products in the Southeast Asian countries not only had the advantages of low cost, both also the low transportation cost and the tariff agreement when selling to countries nearby and to the US. Woo Sun responded to changes in global trends and market demands and took its products into the global market.

This transformation is a system-based (Adams, 1984), structure-based (Lavy and Marry, 1988), strategy-based (Davidson, 1993), and thought-based (Wycoff and Richardson, 1995) transformation. Moving the production base to Vietnam requires a new management system and structure and different thinking.

In recent years, many changes take place in the food industry. In this ever-changing world of global competition, consumer loyalty depends on brand identification. It can be evaluated by data collection of consumers' behavior. Through the most powerful analysis tool, "big data analysis," valuable trends in the data help understand consumer behavior better, create ideal consumer experiences, and conduct the right brand marketing.

\section{CONCLUSION AND FURTHER RESEARCH}

Through the investigation food industry and the case study of the Woo Sun Food Factory Company, it can be concluded that the followings are extremely crucial to an enterprise.

1. Customer Orientation:

Data collection and analysis enable an enterprise to understand consumer buying behaviors in a more precise way, which can provide adjustments directions of marketing and product design to increase customer satisfaction.

2. Expanding Business into New Market:

Combining the traditional physical sales channels and new virtual sales channels helps the companies to improve sales and to be more competitive.

3. Global Market:

Increasing product added values, being a global market player, reaching out for new business opportunities help an enterprise go further.

In summary, Woo Sun's four transformations include system-based transformations (Adams, 1984), structure-based (Lavy and Marry, 1988), strategy-based transformations (Davidson, 1993), and thought-based transformations (Wycoff and Richardson, 1995). Maximizing profits, expanding sales into the global market, and utilizing advantages from different production and sales location is the best return of all the transformations.

By analyzing the development and current situation of the food industry, examining the history and policies, investigating a classic case of the food industry in detail, important factors for the maintenance of competitiveness are concluded.

\section{REFERENCES}

Adams, J. D. (1984). Transforming Work. Alexandria, VA: Miles Review Press. 
Canadean (2013). Global Food Industry Survey 2013-2014 - Market Trends, Buyer Spend, and Procurement Strategies in the Global Food Industry. New York: Reportlinker.

Chang, P. (2006). Taiwan's Quanzhi-Volume 9: Social - Economics, and Society. Taipei: National History Museum Taiwan Archives.

Chi, C. and Xiao X. (2006). Taiwan's Quanzhi-Volume 9: Social - History and Society. Taipei: National History Museum Taiwan Archives.

Davidson, W. H. (1993). Beyond re-engineering: the three-phase of business transformation, IBM Systems Journal, 32(1), 65-79

Food Industry Research and Development Institute (2015). Almanac of Food Industry in the Republic of China on Taiwan. Hsinchu City: Food Industry Research and Development Institute.

Food Industry Research and Development Institute (2018). Almanac of Food Industry in the Republic of China on Taiwan. Hsinchu City: Food Industry Research and Development Institute.

Jeng, H. \& Fang, T. (2003). Food safety control system in Taiwan-The example of the food service sector. Food Control, 14(5), 317-322.

Lavy, A. and Merry U. (1988) Organizational Transformation: Revitalizing Organization for a Competitive World. San Francisco: Jessey-Bass Inc.

Lee, H. (1997). Collection Working Documents on Taiwan Food Industry Development in the Past 50 Years. Taipei: Lee, $\mathrm{H}$.

Porter, M. E. (1979). How competitive forces shape strategy. Harvard Business Review, 57(2), pp. 137145.

Wang, Z. H. (2017) The Value and Preservation of Industrial Heritage for Cannery in Postwar Taiwan. Published master dissertation, Department of Architecture, Chenggong University, Taiwan Tainan.

Wycoff, J., and Richardson, T. (1995). Transformation Thinking: Tools and Techniques that Open the Door to Powerful New Thinking for Every Member of Your Organization. New York City: Berkley Books. 